\title{
Aplikasi Wingeom dan Media Lectora Inspire Sebagai Media Pembelajaran pada Materi Bangun Ruang Geometri
}

\author{
Ardhi Sanwidi
}

\author{
Universitas Nahdlatul Ulama Blitar, Indonesia \\ Email: ardhisanwidi@unublitar.ac.id
}

$\overline{\text { Tersedia Online di }}$
http://www.jurnal.unublitar.ac.id/i
ndex.php/briliant

\begin{tabular}{l}
\hline Sejarah Artikel \\
\hline Diterima pada 11 September 2020 \\
Disetujui pada 18 November 2020 \\
Dipublikasikan pada 30 November \\
2020 \\
Hal. 731 \\
\hline
\end{tabular}

\begin{tabular}{l}
\hline Kata Kunci: \\
\hline Wingeom, Lectora Inspire, Bangun \\
Ruang Geometri \\
\hline
\end{tabular}

\section{DOI:}

http://dx.doi.org/10.28926/briliant. v3i4.548

\begin{abstract}
Abstrak: Penelitian ini bertujuan untuk menghasilkan perangkat pembelajaran yang valid, praktis, dan efektif dengan bantuan media pembelajaran Lectora Inspire dan aplikasi Wingeom pada materi bangun ruang. Penelitian ini merupakan penelitian pengembangan dengan menggunakan lima tahapan (ADDIE) yaitu: tahap analisis (Analysis), desain (Design), pengembangan (Development), implementasi (Implementation), dan evaluasi (Evaluation). Berdasarkan hasil dari validasi ahli bahasa, materi dan media, perangkat dan media yang digunakan dalam pembelajaran memenuhi kriteria valid dengan prosentase sebesar 98\%, serta kepraktisan dalam pembelajaran dilihat dari aktivitas dosen dan mahasiswa dimana pada pertemuan pertama sampai akhir terus meningkat sehingga perangkat dan media yang digunakan dapat dikatakan praktis. Dari penilaian efektif dapat dilihat pada hasil nilai preetest dan posttest mahasiswa dengan nilai signifikan 10,81. Dari hasil analisis dapat dikatakan penggunaan media lectora dan
\end{abstract} wingeom dalam pembelajaran pada materi geometri bidang 3 dimensi ini praktis, valid dan evektif. Penggunaan media lectora dapat membuat pembelajaran menjadi lebih menarik, serta penggunaan aplikasi wingeom mempermudah mahasiswa dalam mengabstraksi bangun 3 dimensi pada materi geometri dan mejadikannya gambar geometri yang abstrak menjadi lebih nyata.

\section{PENDAHULUAN}

Matematika merupakan ilmu yang dipelajari pada semua jenjang pendidikan, karena matematika berperan penting dalam upaya penguasaan ilmu dan teknologi. Dengan belajar matematika diharapkan dapat menumbuh kembangkan kemampuan dan pribadi yang sejalan dengan tuntutan kehidupan masa depan. Geometri dapat dikatakan sebagai salah satu materi yang dianggap penting dalam matematika, karena geometri membantu manusia memiliki aspirasi yang utuh tentang dunianya dan digunakan oleh banyak orang dalam kehidupan sehari-hari, dengan geometri dapat membantu mengembangkan keterampilan spasial dan penuh teka - teki yang menarik untuk dipecahkan. Selain itu geometri juga memerankan peranan penting bagi materi pelajaran yang lain (Van de Walle, 2016)

Materi geometri memerlukan keakuratan dalam mengkontruksi atau menggambar sebuah bangun 2 dimensi maupun 3 dimensi. Menggambar bangun geometri memerlukan keakuratan dan waktu yang lama, serta kesulitan dalam pembuktian teorema Euclid tanpa menggambar bangun yang tepat dan akurat. Ketepatan dan keakuratan dalam menggambar bangun geometri sangat penting, 
karena menggambar dalam geometri merupakan peranan penting yang mnghubungkan antara ruang fisik dan teori (Hernawati dkk, 2013). Studi pendahuluan yang dilakukan di Universitas Nahdlatul Ulama Blitar menemukan bahwa perkuliahan masih menggunakan buku teks dan masih menggunakan pembelajaran konvensional dimana mahasiswa kurang aktif dalam pembelajaran. Mahasiswa belum bisa menyelesaikan persoalan geometri yang kaitannya dengan bangun ruang, serta mahasiswa sulit untuk mengabstraksi gambar 3 dimensi pada geometri. Mahasiswa melakukan banyak kesalahan ketika menyelesaikan soal-soal mengenai bangun ruang, hal ini bisa disebabkan karena mahasiswa masih belum mengerti dengan materi tersebut serta kurangnya media untuk membuat siswa mudah untuk mengabstraksi bangun ruang 3 dimensi. Didukung penelitian Sofnidar dkk (2013) dan Pratiwi \& Septia (2016) menyebutkan bahwa masih banyak kesalahan konsep dasar geometri yang terlihat pada mahasiswa, seperti tidak jelasnya perbedaan sifat-sifat masing-masing bangun 3D.

Studi pendahuluan yag dilakukan, ditemukan adanya kelemahan dalam proses pembelajaran, dimana masih mengunakan pembelajaran langsung, dimana masih berpusat pada pemberian materi oleh dosen. Adanya kelemahan dalam pembelajaran langsung yang bersifat konvensional dimana mahasiswa kurang aktif dalam proses pembelajaran, perlu ada suatu upaya untuk mengatasi hal tersebut dengan menggunakan model, metode dan media pembelajaran secara tepat dalam pembelajaran (Ariani \& Harganto, 2010). Menggunakan media pembelajaran yang interaktif dan menarik membuat mahasiswa dan dosen akan terlibat aktif dalam pembelajaran (Sanwidi \& Swatika, 2019). Media merupakan perantara atau saluran komunikasi untuk menyampaikan pesan atau pendapat atau informasi kepada penerima pesan (Kustandi \& Sucipto, 2011; Kemp \& Dayton, 1985).

Penggunaan media dalam pembelejaran memungkingkan mahasiswa untuk mendapatkan pemahaman dan keyakinan yang lebih baik sebelum mencoba suatu bukti formal atau pembuktian. Salah satu media pembelajaran yang dapat digunakan adalah Lectora Inspire. Lectora Inspire merupakan software pengembangan belajar elektronik (e-learning) yang relatif mudah diaplikasikan atau diterapkan karena tidak memerlukan pemahaman bahasa pemrograman yang canggih. Media Lectora Inspire familiar dengan peserta didik maupun pendidik yang telah mengenal maupun menguasai Microsoft Office.

Penggunaan Lectora pada mata kuliah Geometri dapat didesain dan dibuat beberapa slide, menampilkan video animasi, serta gambar - gambar yang berhubungan dengan teori - teori pada geometri agar mahasiswa lebih memperhatikan apa yang disampikan Mas'ud (2012). Penggunaan media lecotra inspire akan meningkatkan aktivitas belajar (Sanwidi \& Swastika, 2018). Selain media Lectora Inspire, salah satu program aplikasi komputer yang mendukung pembelajaran adalah program Wingeom. Pratiwi \& Septia (2016) mengungkapkan bahwa program Wingeom dapat membantu memvisualisasikan suatu konsep geometri dengan jelas sehingga mahasiswa akan lebih mudah memahami konsepkonsep geometri. Dengan program Wingeom, mahasiswa dapat mengeksplorasi, mengamati, melakukan animasi bangun-bangun dan tampilan materi geometri.

\section{METODE}

Pengembangan perangkat ini menggunakan model pengembangan ADDIE yang terdiri dari lima tahapan yaitu tahap analisis (analysis), desain (design),

722 BRILIANT: Jurnal Riset dan Konseptual Volume 5 Nomor 4, November 2020 
pengembangan (development), implementasi (implementation), dan evaluasi (evaluation). Tahap analisis terdiri dari analisis silabus mata kuliah, buku ajar geometri, analisis wawancara dosen dan mahasiswa, analisis kebutuhan mahasiswa terhadap software. Tahap desain terdiri dari merancang perangkat pembelajaran dan media pembelajaran. Evaluasi diri dilakukan terhadap rancangan perangkat guna mendapatkan rancangan yang sesuai dengan hasil tahap analisis. Tahap pengembangan terdiri dari validasi oleh para ahli atau validator, serta berdasarkan hasil evaluasi diri pada tahap desain. Tahap implementasi dengan mengujicobakan perangkat yang telah dikembangkan. Uji coba dilakukan untuk kelompok kecil dengan desain uji coba quasi experiment. Hasil uji coba dapat dilihat melalui nilai pretest dan postest mahasiswa.

Subjek penelitian pada penelitian ini adalah mahasiswa matematika Univesitas Nahdlatul Ulama Blitar semester 2 yang sedang menempuh mata kuliah geometri dimana mengambil 10 mahasiswa dengan random sampling sebagai kelompok kecil uji coba perangkat yang sudah dibuat. Intrumen penelitian berupa soal atau pertanyaan mengenai geometri 3 dimensi, lembar respon mahasiswa, serta angket yang ditujukan kepada validator untuk menilai kevalidan perangkat. Instrumen dalam penelitian ini berupa SAP (Satuan Ajaran Perkuliahan), MLW (Media Lectora dan Wingeom). Pengumpulan data dilakukan dengan menggunakan lembar validasi untuk para ahli untuk memvalidasi SAP dan MLW, melakukan observasi untuk mengambil data dosen dalam melakukan perkuliahan, data mahasiswa dan aktivitasnya, serta respon mahasiswa. Selain itu dilakukan tes terhadap mahasiswa (preetest dan posttest) untuk melihat keefektifan perangkat dan media pembelajaran. Perangkat serta media pembelajaran berkualitas baik dapat dilihat dari kevalidan, kepraktisan serta keefektifan perangkat. Perangkat dikatakan valid jika skor rata - rata koefisien lebih dari 0,6 atau serendah - rendahnya memenuhi interpretasi baik. Perangkat dikatakan praktis jika ada aktifitas penggunsan persngkat meningkat. Serta dikatakan efektif jika adanya peningkatan mutu nilai dari mahasiswa.

\section{HASIL}

Pengembangan yang dilakukan dalam penelitian menggunakan model ADDIE (Analysis, Design, Development, Implementation, Evaluation). Pada tahap analisis, dilakukan analisis pada SAP yang digunakan oleh dosen sebelumnya, analisis pada materi dan bahan ajar yang digunakan, serta media yang digunakan. Dari tahap aalisis dilanjutkan pada tahap mendesain SAP dan MLW sesuai kebutuhan dan pengembangan dari SAP sebelumnya. Pada tahap pengembangan, peneliti melakukan uji coba perangkat dan melakukan validasi kepada para ahli dengan menggunakan lembar validasi untuk mengambil data kevalidan perangkat dan media yang digunakan. Analisis data hasil validasi rumus alat pembelajaran untuk mengetahui validitas instrumen alat pembelajaran tersebut adalah sebagai berikut: $\gamma=\frac{\mathrm{N} \sum \mathrm{WX}-\left(\sum \mathrm{W}\right)\left(\sum \mathrm{X}\right)}{\sqrt{\left(\mathrm{N} \sum \mathrm{W}^{2}-\mathrm{W}^{2}\right)\left(\mathrm{N} \sum \mathrm{X}^{2}-\mathrm{X}^{2}\right)}}$.

" $\mathrm{N}$ " merupakan banyaknya indikator yang ada pada isntrumen, "W" merupakan perolehan skor yang diperoleh dari validator 1, " $X$ " merupakan perolehan skor yang diperoleh dari validator 2. Berikut hasil validasi dan interpretasi yang ditunjukkan dalam tabel 1 . 
Tabel 1: Koefisien validitas dan interpretasinya

\begin{tabular}{cccc}
\hline No & Perangkat / Media & Koefisien Validitas & Interpretasi \\
\hline $\mathbf{1}$ & SAP & 0,97 & Sangat Tinggi \\
\hline $\mathbf{2}$ & Lectora Inspire & 0,98 & Sangat Tinggi \\
\hline $\mathbf{3}$ & Wingeom & 0,98 & Sangat Tinggi \\
\hline
\end{tabular}

Dari tabel 1 terlihat bahwa SAP dan MLW yang telah dibuat memiliki koefisien validitas yang sangat tinggi, sehingga perangkat pembelajaran yang telah digunakan dapat dikatakan valid. Pada tahap pengembangan dan ujicoba peneliti telah melakukan beberapa perubahan atau revisi dari perangkat yang telah dikembangkan, serta perubahan dari masukkan para ahli supaya perangkat SAP dan MLW yang dikembangkan ini lebih baik. Berikut gambar 2 yang merupakan cuplikan media Lectora dan gambar 3 yang merupakan cuplikan media Wingeom, media yang digunakan.

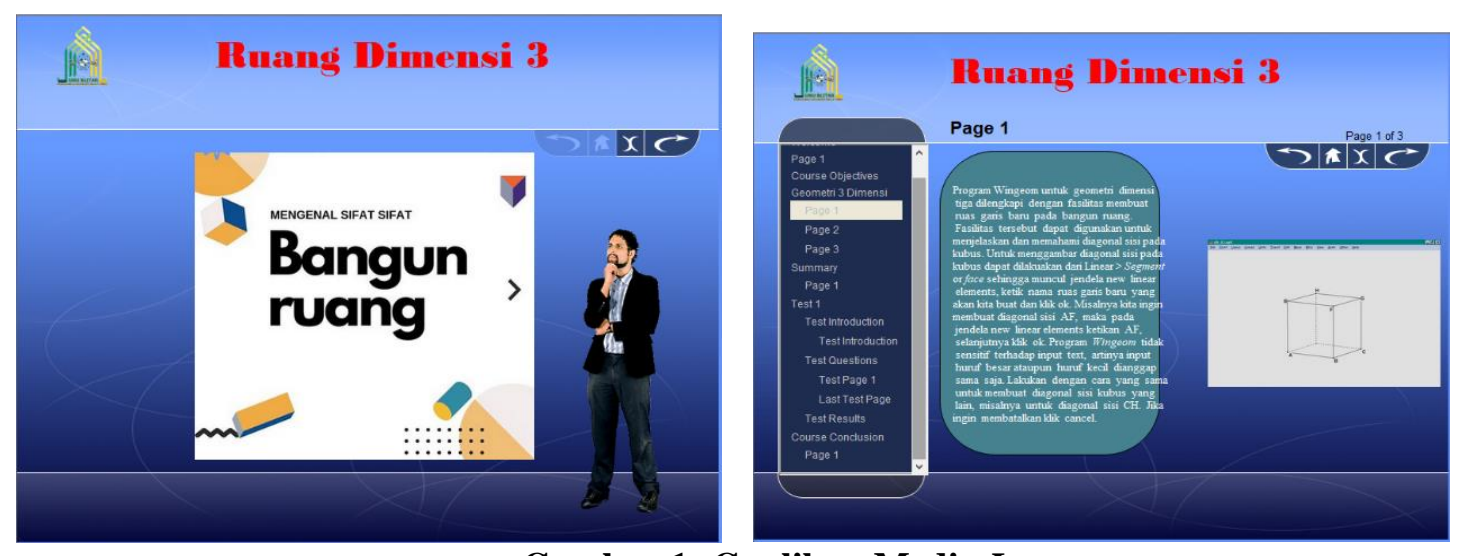

Gambar 1: Cuplikan Media Lectora

Gambar 1 merupakan cuplikan dari media Lectora Inspire yang digunakan dalam pembelajaran. Pengembangan penggunaan aplikasi tersebut berdasarkan kebutuhan mahasiswa untuk mempermudah dalam belajar bangun ruang dimensi 3 geometri. Pengembangan media tersebut juga dari berbagai masukkan dari beberapa validator, dalam hal ini adalah ahli bidang pendidikan matematika, supaya media lebih mudah terbaca, interaktif, dan menarik. Untuk mempermudah mahasiswa dalam mengabstraksi dan mudah memahami pelajaran geometri kususnya bidang 3 dimensi, maka digunakan bantuan aplikasi Wingeom untuk membuat objek 3 dimensi dari materi geomentri seperti kubus dan balok menjadi lebih nyata. Berikut cuplikan aplikasi wingeom yang digunakan dalam pembelajran yang dilakukan. 

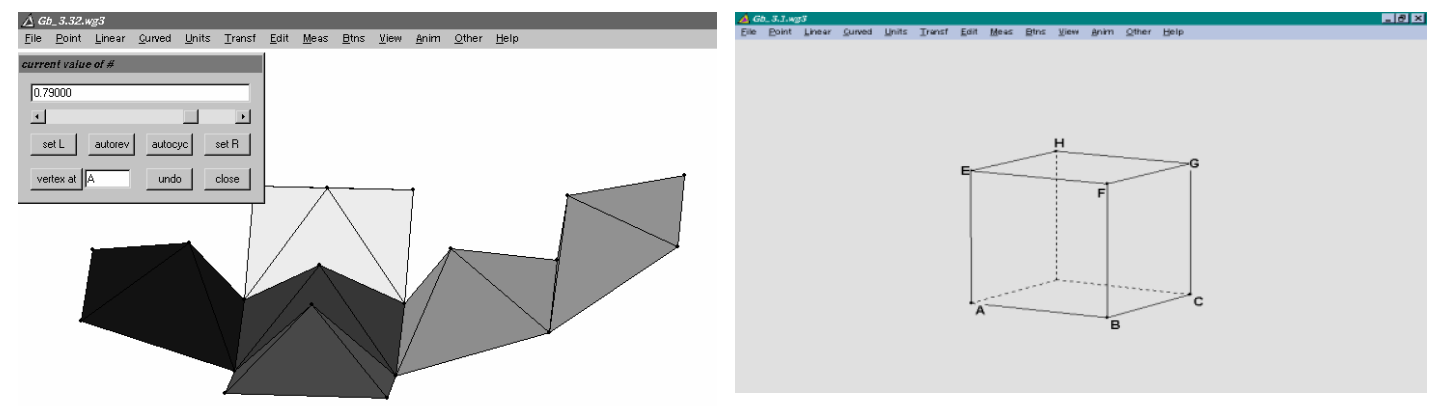

Gambar 2: Cuplikan Media Wingeom

Gambar 2 merupakan cuplikan dari media Wingeom yang digunakan. Dengan menggunakan aplikasi wingeom mempermudah mahasiswa maupun dosen dalam membuat gambar bidang 3 dimensi geometri. Cuplikan gambar 3 diatas merupakan pengembangan dan hasil dari validasi ahli serta masukkan dari dosen pengampu matakuliah yang disesuaikan dengan tujuan pembelajaran yang ada. Pada tahap evaluasi, peneliti mengevaluasi hasil prototipe yang telah dibuat dengan beberapa masukan dan validasi ahli.

Dari hasil pengembangan, dilakukan ujicoba atau implementasinya kepada mahasiswa. Perangkat pembelajaran dinilai praktis jika aktivitas dosen dan mahasiswa dalam pembelajaran mencapai kategori baik (kategori aktivitas $\geq 80 \%$ dari data hasil observasi). Berikut adalah gambar prosentasi dari aktivitas dosen dan mahasiswa.

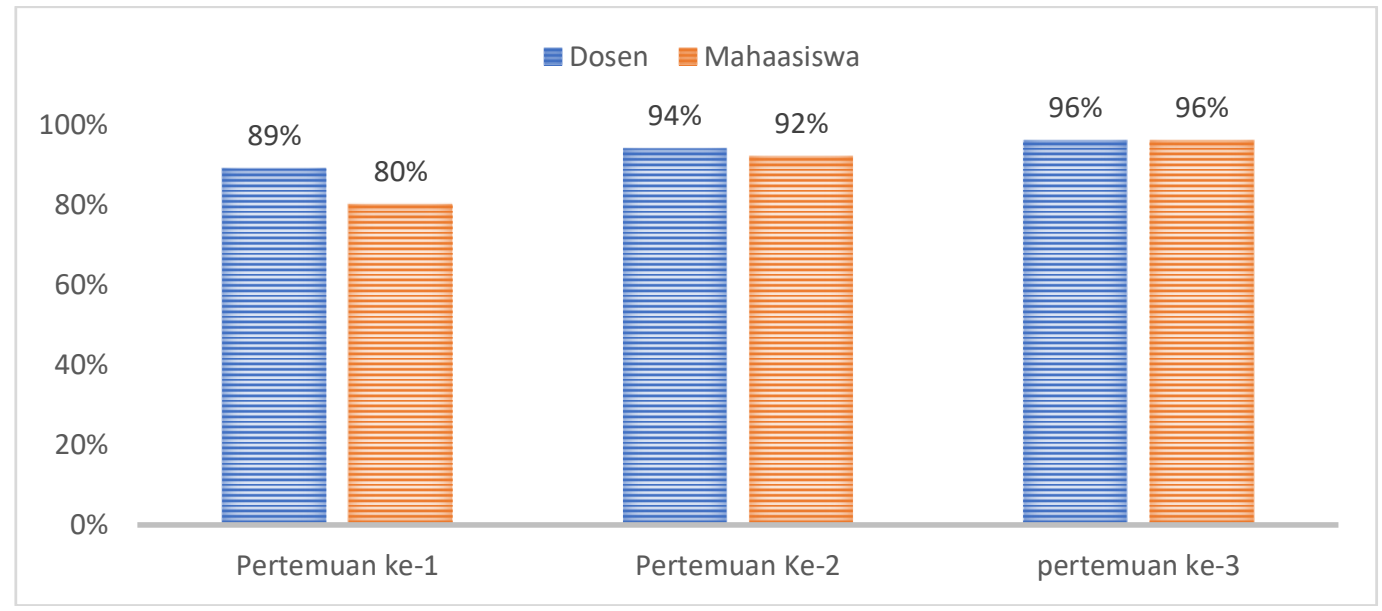

Gambar 3: Prosentase Aktifitas Dosen dan Mahasiswa

Dari gambar 3, dapat dilihat bahwa prosentase aktivitas mahasiswa pada pertemuan pertama mencapai $80 \%$ dan meningkat pada pertemuan kedua sebesar $92 \%$, serta pada pertemuan ketiga mengalami peningkatan sebesar $96 \%$. Begitu pula dengan aktivitas yang dilakukan oleh dosen mengalami peningkatan dari $89 \%$ ke $96 \%$ dan pada pertemuan ketiga sebesar 96\%. Dapat dilihat bahwa aktifitas pembelajaran mahasiswa meningkat dari pertemuan pertama sampai ketiga.

Pada tahap implementasi dan evaluasi, implementasi dilakukan pada kelompok kecil melibatkan 10 mahasiswa mewakili mahasiswa yang mengambil matakuliah geometri. Sebelum mahasiswa mempeloeh pengajaran dengan perangkat ini, dilakukan preetest untuk melihat kemampuan awal mahasiswa, 
selajutnya diberikan perkuliahan dengan menggunakan perangkat dan media yang telah dikembangkan. Setelah dilakukan pengajaran, hasil pekerjaan mahasiswa dievaluasi untuk melihat pemahaman konsep geometri bidang dimensi 3 berbantuan media Lectora Inspire dan aplikasi Wingeom. Berikut tabel data hasil pretest dan posttest dilihat berdasarkan ukuran penyebaran data.

Tabel 2. Deskripsi Penyebaran data Pretest dan Postest

\begin{tabular}{cccccc}
\hline Perlakuan & N & Mean & Std. Deviasi & $\boldsymbol{x}_{\max }$ & $\boldsymbol{x}_{\min }$ \\
\hline Pretest & 10 & 68,4 & 1,5776 & 70 & 66 \\
\hline Postest & 10 & 77,4 & 3,2728 & 82 & 72 \\
\hline
\end{tabular}

Dari tabel 2 diatas dapat terlihat dengan jumlah responden 10 orang dengan rata-rata pretest diperoleh 68,4 dan posttest sebesar 77,4. Untuk mengetahui perbedaan hasil pretes dan postest, analisis yang digunakan adalah uji-t data berpasangan. Terima $\mathrm{H}_{0}$ jika $t_{\text {hitung }}>t_{\text {tabel }}$ ini berarti ada perbedaan yang signifikan antara nilai pretest dan postest. Selanjutnya kita uji-t, diperoleh standart deviasi perbedaan skor antara nilai pretest dan posttest sebesar 2,5 serta standart error dari mean perbedaan nilai pretest dan posttest sebesar 0,80 . Selanjutnya dari hasil uji-t diperoleh $t_{\text {hitung }}$ sebesar $(-10,81)$ dan nilai $t_{\text {tabel }} 2,3$. Tanda negatif menandakan terdapat nilai selisis perbedaan.

\section{PEMBAHASAN}

Perangkat yang dihasilkan dalam penelitian ini adalah Satuan Acara Perkuliahan (SAP) dan Media Lectora dan Wingeom (MLW). Uji kevalidan dilakukan dengan memvalidasi kepada 2 ahli dibidangnya. Hasil validasi oleh 2 validator diperoleh bahwa koefisien validatas untuk SAP sebesar 0.97, sedangkan untuk media lectora dan wingeom masing-masing sebesar 0,98 dengan intepretasi data sangat tinggi. Dari data yang diperoleh dapat dinyatakan bahwa perangkat dan media yang dihasilkan valid.

Untuk memenuhi kriteria kepraktisan dapat dilihat dari aktivitas dosen dan mahasiswa dalam kegiatan pembelajaran dengan menggunakan perangkat yang telah dikembangkan. Dari gambar 2 dapat terlihat bahwa aktifitas dosen dan mahasiswa meningkat dari pertemuan pertama sampai pertemuan selanjutnya. Pada pertemuan pertama, aktifitas dosen masih lebih tinggi dari pada mahasiswa, karena mahasiswa masih menyesuaikan dengan pembelajarannya. Pada pertemuan kedua dan ketiga aktifitas dosen dan mahasiswa meningkat. Hal ini menunjukkan bahwa perangkat pembelajaran dapat dikatakan praktis dengan prosentase aktivitas dosen dan mahasiswa lebih dari 80\% (Fidan \& Türnüklü, 2010)

Kriteria kualitas perangkat pembelajaran yang baik selanjutnya adalah dilihat dari kriteria keefektifan. Keefektifan dari perangkat ini dapat terlihat dari hasil tes mahasiswa uji coba. Dari hasil tes menunjukkan bahwa hasil belajar mahasiswa mengalami perbedaan yang signifikan berdasarkan nilai tes awal (preetest) dan nilai tes akhir (posttest) sebesar 10,81. Dari data hasil uji coba serta analisis yang dilakukan menunjukkan bahwa terjadi peningkatan nilai rata-rata mahasiswa dari preetest dan posttest.

\section{KESIMPULAN}

726 BRILIANT: Jurnal Riset dan Konseptual

Volume 5 Nomor 4, November 2020 
Analisis pendahuluan yang dilakukan dengan analisis silabus, wawancara dosen dan mahasiswa, serta analisis kebutuhan untuk mendukung pembelajaran diperoleh bahwa mahasiswa mengalami kesulitan dalam mengabstraksi gambar 3 dimensi pada materi geometri bidang 3 dimensi serta mahasiswa banyak mengalami kesalahan ketika mengerjakan permasalah mengenai geometri bidang 3 dimensi. Penggunaan media lectora inspire dan aplikasi wingeom yang digunakan dalam pembelajaran dan perangkat yang dihasilkan memiliki kriteria praktis, valid dan efektif. Penggunaan media lectora serta aplikasi wingeom efektif dalam meningkatkan prestasi mahasiswa yang dapat dilihat dari hasil preetest dan postest yang dilakukan terdapat perbedaan yang signifikan dimana postest rata-ratanya lebih tinggi dari nilai preetest. Selain itu penggunaan media letora membuat mahasiswa lebih tertarik dalam mempelajari geometri kususnya bidang 3 dimensi. Aplikasi wingeom dapat mempermudah mahasiswa dalam mengabstraksi bidang 3 dimensi sehingga mahasiswa dapat menyelesaikan permasalahan yang terkait dengan materi geometri bidang 3 dimensi dengan lebih menarik.

\section{SARAN}

Berdasarkan uraian hasil penelitian, diharapkan semua pihak yang terlibat dalam proses pembelajaran matematika dapat mengedepankan penggunaan media untuk mempermudah peserta didik baik mahasiswa maupun siswa dalam belajar matematika. Diharapkan penggunaan media Letcora inspire dan Wingeom dapat terus ditingkatkan dan dilakukan dalam pembelajaran matematika khususnya geometri maupun pembelajaran yang lain.

\section{DAFTAR RUJUKAN}

A. Sanwidi and G. T. Swastika, "Lectora Inspire in Learning Congruence Triangles in Higher Education," JIPM (Jurnal Ilm. Pendidik. Mat., vol. 7, no. 1, p. 66, 2018.

A. Sanwidi and G. T. Swastika, "Direct learning models assisted by Lectora Inspire media to improve the understanding of geometry concepts," J. Phys. Conf. Ser., vol. 1188, p. 012061, 2019.

D. Sofnidar et al., "Penerapan Pendekatan PMRI untuk Meningkatkan Kemampuan Konsep Geometri Mahasiswa PGSD Universitas Jambi,” pp. 489-504, 2013.

Fidan Y and Türnüklü E, "Examination of 5th grade students' levels of geometric thinking in terms of some variables", Pamukkale University Journal of Education, 2010.

J. A. Van de Walle, Elementary and Middle School Mathematics, Sixth edit. Virginia Commonwealth University, 2016.

K. Hernawati et al., "Pengembangan perangkat pembelajaran geometri berbasis ict untuk meningkatkan kemampuan komunikasi matematis mahasiswa," Semin. Nas. Mat. dan Pendidik. Mat., pp. 1-6, 2013.

Kemp, J. E. \& Dayton, D. K., Planning and producing instructional media. New York: Harper and Row Publisher, 1985.

Kustandi, Cecep \& Bambang Suctipto, Media Pembelejaran Manual dan Digital. Bogor: Ghalia Indonesia, 2011. 
M. Pratiwi and T. Septia, "Efektifitas Modul Aplikasi Komputer Dengan Program Wingeom pada Materi Geometri," LEMMA, vol. III, no. 1, pp. 97-107, 2016.

Mas'ud, Muhammad, Membuat Multimedia Pembelajaran dengan Lectora, Yogyakarta:Shonif, 2012.

N. Ariani and D. Haryanto, Pembelajaran Multimedia di Sekolah Pedoman Pembelajaran Inspiratif, Konstruktif, dan Prospektif. Jakarta: Prestasi Pustaka, 2010. 